\title{
Toxicological evaluation of lactose and chitosan delivered by inhalation
}

\author{
M. J. DE JESÚS VALLE ${ }^{1}$, R. J. DINIS-OLIVEIRA ${ }^{2}$, F. CARVALHO ${ }^{2}$, \\ M. L. BASTOS ${ }^{2}$ and A. SÁNCHEZ NAVARRO ${ }^{1, *}$ \\ ${ }^{1}$ Pharmacy Department, University of Salamanca, Licenciado Méndez, Nieto, s/n. 37007, \\ Salamanca, Spain \\ ${ }^{2}$ Department of Toxicology, Faculty of Pharmacy, University of Porto, Rua Anibal Cunha 164, \\ 4099-030 Porto, Portugal
}

Received 15 May 2007; accepted 5 September 2007

\begin{abstract}
These days, inhalation constitutes a promising administration route for many drugs. However, this route exhibits unique limitations, and formulations aimed at pulmonary delivery should include as few as possible additives in order to maintain lung functionality. The purpose of this work was to investigate the safety of lactose and chitosan to the pulmonary tissue when delivered by inhalation. The study was carried out with 18 Wistar rats divided in three groups receiving distilled water, lactose or chitosan. A solution of each excipient was administered by inhalation at a dose of $20 \mathrm{mg}$. The lungs were excised and processed to determine several biochemical parameters used as toxicity biomarkers. Protein and carbonyl group content, lipid peroxidation, reduced and oxidized glutathione (GSSG), myeloperoxidase (MPO), cooper/zinc and manganese superoxide dismutase, catalase, glutathione S-transferase and glutathione peroxidase were determined. Results of myeloperoxidase activity and glutathione disulfide lung concentrations showed a relevant decrease for chitosan group compared to control: $4.67 \pm 2.27$ versus $15.10 \pm 7.27(P=0.011)$ for MPO and $0.89 \pm 0.68$ versus $2.02 \pm 0.22(P=0.014)$ for GSSG. The other parameters did not vary significantly among groups. Lactose and chitosan administered by inhalation failed to show toxic effects to the pulmonary tissue. A protective effect against oxidative stress might even be attributed to chitosan, since some biomarkers had values significantly lower than those observed in the control group when this product was inhaled. Nevertheless, caution must be taken regarding chemical composition and technological processes applied to incorporate these products during drug formulation, in particular for dry powder inhalators.
\end{abstract}

Key words: Chitosan; enzymatic activity methods; excipient safety; lactose; pulmonary delivery.

\footnotetext{
${ }^{*}$ To whom correspondence should be addressed. Tel.: (34-923) 294-536; Fax: (34-923) 294-515; e-mail: asn@usal.es
} 


\section{INTRODUCTION}

Inhalation nowadays constitutes one of the most promising administration routes for many drugs, such as those of biotechnological origin not suitable for oral administration, and also for other drugs used for the treatment of specific diseases associated with the lung. Pulmonary delivery has many advantages over other routes, although it also exhibits unique limitations [1, 2]. Formulations aimed at pulmonary delivery should include as few as possible additives in order to maintain lung functionality and to avoid respiratory pattern modifications since administration of substances by inhalation raises specific safety concerns. New technological strategies for the drug to reach the proper part of the pulmonary tree and to remain as a depot for a desired period of time are being investigated and recently applied. Lactose and chitosan have been proposed as auxiliary substances for inhalation formulations, the former widely used in the pharmaceutical industry as excipient in preparations given also by other routes of administration [3-6]. Notwithstanding, the literature is devoid of comprehensive reviews of lactose safety when aimed at pulmonary delivery and most available data come from studies performed to assess the potential toxicity of formulations containing an active drug in the presence of lactose instead of evaluating lactose per se. Most results from these inhalation studies revealed no finding of toxicological significance with lactose although some of them comprised cases of minimal peribronchiolar lymphoid hyperplasia in the lungs and carina and also lymph node lymphocyte depletion together with alveolar macrophage infiltration in the lungs [7]. However, a causal relationship between lactose and these effects is yet to be disclosed. Several human studies [8,9] have also evaluated the pharmacological effects of antiasthmatic drugs when formulated as dry powder in presence and absence of lactose but only one [10] examined the effect of lactose per se in subjects with asthma and bronchial hyperresponsiveness. Results showed that large doses of lactose powder (600 mg over $20 \mathrm{~min}$ ) inhaled through this form had little bronchoconstrictor or irritant effect on the airways of the asthmatic subjects. Regarding chitosan, this term is used to describe a series of polymers with different molecular weights, viscosity and degree of deacetylation [11]. Derived from a naturally occurring source, this polymer has shown to be both biocompatible and biodegradable [12]. The oral $\mathrm{LD}_{50}$ for mice, $16 \mathrm{~g} / \mathrm{kg}$, indicates a very low-toxicity potential for this product [13]. It is an approved food additive that has been considered for pharmaceutical formulation and drug delivery applications, in which attention has been focused on its absorption-enhancing, controlled release and bioadhesive properties.

Recently, chitosan-based delivery systems have been proposed to increase the bioavailability of drugs both at the nasal mucosa and in the lungs [14-16]; also these systems have been reported as efficient vehicles for pulmonary gene delivery [17-19] and several other important applications are being investigated $[11,16,20,21]$. Nevertheless chitosan is not included in the FDA Inactive Ingredient Guide and very sparse data on its pulmonary toxicity are available. 
Pharmaceutical excipients have a vital role in drug formulations; however, few toxicological data are available for many well-known excipients as those mentioned above [22].

Considering the aforementioned putative pro-inflammatory effects of inhaled chitosan and lactose, it is of interest to evaluate the effect of inhalation of these products on pulmonary neutrophil infiltration and putative neutrophil-mediated oxidative stress. In fact, the generation of reactive oxygen species (ROS) from stimulated neutrophils is thought to play an important role in host defence and tissue damage, but may also lead to oxidative stress [23]. When neutrophils become activated, they initiate a "respiratory burst" by consuming molecular oxygen $\left(\mathrm{O}_{2}\right)$, resulting in the formation of superoxide radical $\left(\mathrm{O}_{2}^{*}\right)$ via the action of a plasma-membrane NADPH oxidase. $\mathrm{O}_{2}^{--}$is important as the primary product for the neutrophil-induced generation of ROS but is quickly converted to hydrogen peroxide $\left(\mathrm{H}_{2} \mathrm{O}_{2}\right)$ spontaneously or by the enzyme superoxide dismutase (SOD). $\mathrm{H}_{2} \mathrm{O}_{2}$ is not an inherently reactive compound, but can be transformed into highly reactive and deleterious products: (i) the interactions of $\mathrm{H}_{2} \mathrm{O}_{2}$ with $\mathrm{O}_{2}^{--}$or with trace levels of transition metals can lead to the formation of hydroxyl radicals $\left(\mathrm{HO}^{\bullet}\right)$; (ii) MPO, a hydrogen peroxide oxidoreductase that is specifically found in mammalian granulocytic leukocytes, including neutrophils, monocytes, basophils and eosinophils, contributes considerably to the bactericidal capabilities of these cells via formation of $\mathrm{HOCl}$ from $\mathrm{H}_{2} \mathrm{O}_{2}$ and chlorine ions. Although the responses of neutrophils to different stimulating conditions and pathogens are generally beneficial for host defence, they can be deleterious to the organism if these cells are inappropriately activated, mainly through oxidative stress.

Oxidative stress at sub-cellular level is a complex issue not able to be defined with a single parameter. There are no available standardized methods to evaluate this state in humans yet but a series of biomarkers of oxidative stress have been proposed to make an overall estimation. Among these biomarkers the following are widely used: (i) thiobarbituric acid reactive substances (TBARS) as indicative of lipid peroxidation (LPO) [24]; (ii) carbonyl groups content to evaluate the degree of oxidative proteins modification [25]; (iii) antioxidant enzymes activities, including glutathione peroxidase (GPx), catalase (CAT), glutathione S-transferase (GST) and copper/zinc and manganese superoxide dismutase (Cu/Zn SOD and MnSOD, respectively), which have been found to be inducible in different cells in response to oxidative stress [26]; (iv) myeloperoxidase (MPO), located within the primary azurophil granules of polymorphonuclear (PMN) leukocytes, whose activity indirectly reflects PMN infiltration through the organs during the inflammatory reaction [27].

The present study was aimed at evaluating the above biochemical parameters as biomarkers of toxicological effects of lactose and chitosan per se on the respiratory system when directly exposed to each product by inhalation route. This type of information is not available yet despite a wide research on pulmonary delivery of lactose- and chitosan-containing formulations. 


\section{MATERIALS AND METHODS}

\section{Chemicals}

$\alpha$-Lactose monohydrate $(\beta$-D-Gal-(1 $\rightarrow 4)-\alpha$-D-Glc4-O- $\beta$-D-Galactopyranosyl$\alpha$-D-glucose), chitosan (chitosan from crab shells $\geqslant 75 \%$ (deacetylated) (2amino-2-deoxy-( $\rightarrow$ 4)- $\beta$-D-glucopyranan, molecular mass $31 \mathrm{kDa})$, L-Glutamic acid, $3,3^{\prime}, 5,5^{\prime}$-Tetramethylbenzidine (TMB), NADPH ( $\beta$-nicotinamide adenine dinucleotide phosphate reduced), GSH (L-glutathione reduced), GSSG (L-glutathione oxidized), 2-Vinylpyridine, DNPH-2,4-dinitrophenylhydrazine, GSH reductase (Glutathione Reductase from bakers yeast), $\mathrm{H}_{2} \mathrm{O}_{2}$, sodium azide $\left(\mathrm{NaN}_{3}\right), \mathrm{CDNB}$ (1-chloro-2,4-dinitrobenzene) and xanthine oxidase were all obtained from Sigma (Germany). Saline solution $(\mathrm{NaCl} 0.9 \%)$ and sodium thiopental $(0.5 \mathrm{~g})$ were obtained from B. Braun (Spain). Sodium hydroxide $(\mathrm{NaOH}), 2$-thiobarbituric acid $\left(\mathrm{C}_{4} \mathrm{H}_{4} \mathrm{~N}_{2} \mathrm{O}_{2} \mathrm{~S}\right)$ and trichloroacetic acid $\left(\mathrm{Cl}_{3} \mathrm{CCOOH}\right)$, ethylenedinitrotetracetic acid disodium salt dihydrate ( $\mathrm{Na}_{2}$ EDTA) were obtained from Merck (Germany).

\section{Experimental protocol}

18 Wistar male rats from Charles River (Spain) with a mean body weight of $308.17 \pm 17.64 \mathrm{~g}$ were included in the study. Twelve hours prior the experiment, animals were isolated in cages and allowed access to tap water ad libitum. Housing and experimental treatment of animals were in accordance with the corresponding Guide from the Institute for Laboratory Animal Research (ILAR 1996). The experiments complied with the current laws of Portugal and Spain and adhere to the "Principles of Laboratory Animal Care". Animals were randomly distributed into the following groups of 6 rats each: (i) control group, exposed to distilled water; (ii) lactose group, exposed to $1 \% \mathrm{w} / \mathrm{w}$ lactose in distilled water and (iii) chitosan group, exposed to $1 \%(\mathrm{w} / \mathrm{w}$ ) chitosan in $0.1 \mathrm{M}$ glutamic acid adjusted to $\mathrm{pH} 7.4$ with $10 \mathrm{M} \mathrm{NaOH}$.

\section{Pulmonary exposure}

After weighing, the animals were anesthesized with sodium thiopental $(80 \mathrm{mg} / \mathrm{kg}$, intraperitoneal route). Then tracheotomy and tracheal cannulation were performed with animals in the decubito supino position and immediately the cannula was connected to a mechanical ventilation system (7025 Rodent Ventilator, Ugo Basile, Italy) set at 60 respirations per min and $2 \mathrm{ml}$ of tidal volume. $1000 \mathrm{IU}$ sodium heparin was injected by i.p. route to avoid clotting. A stabilization period of $5 \mathrm{~min}$ was allowed prior starting inhalation. Water, lactose or chitosan solution (according to rat group) were nebulized with aid of a nebulizer equipment (Ultrasonic Aerosol Generator 700700-UV TSE system) connected to the artificial ventilation system in such a way that the nebulized product came to the lungs through the cannula for $40 \mathrm{~min}$ (total amount of excipient $20 \mathrm{mg}$ ). After this nebulization period the nebulizer was disconnected and the animals were kept on mechanical ventilation 
until the end of experiment. In situ organ perfusion through the portal vein was performed for 3 min with cold $0.9 \%$ saline solution at a perfusion rate of $10 \mathrm{ml} / \mathrm{min}$ (Minipuls ${ }^{\circledR}$ Gilson 3 pump) in order to clean the tissues from blood. Simultaneously to the perfusion initiation, a cut at the abdominal aorta artery was done to avoid overpressure. Then the thoracic cavity was open, the lungs removed, weighed and processed as follows: the left lung lobe was dissected, and homogenized (Ultra-Turrax ${ }^{\circledR}$ Homogenizer) in a cold aqueous solution of $5 \%(\mathrm{w} / \mathrm{w}) \mathrm{HClO}_{4}$ at a proportion of $1 \mathrm{~g}$ tissue $/ 4 \mathrm{ml}$ solution. Aliquots of the resulting supernatants were immediately used for evaluating the degree of LPO through the quantification of TBARS. The remaining supernatants were stored $\left(-80^{\circ} \mathrm{C}\right)$ for posterior quantification of GSH and GSSG. The pellet was used for the quantification of protein carbonyl groups. The rest of lung tissue was homogenized (Ultra-Turrax ${ }^{\circledR}$ Homogenizer) in a cold mixture of phosphate buffer $\left(\left(\mathrm{KH}_{2} \mathrm{PO}_{4}+\mathrm{Na}_{2} \mathrm{HPO}_{4} \cdot \mathrm{H}_{2} \mathrm{O}\right) 50 \mathrm{mM}, \mathrm{pH} 7.4\right)$ and $0.1 \%(\mathrm{v} / \mathrm{v})$ Triton X-100, $1 \mathrm{~g}$ tissue $/ 4 \mathrm{ml}$ mixture. An aliquot for protein levels quantification was taken before centrifugation $\left(3000 \times g, 4^{\circ} \mathrm{C}\right.$, for $\left.10 \mathrm{~min}\right)$. Aliquots of the resulting supernatants were stored $\left(-80^{\circ} \mathrm{C}\right)$ for posterior quantification of antioxidant enzyme activities.

\section{Protein quantification}

Protein quantification was performed according to the method of Lowry et al. [28], using bovine serum albumin as standard.

\section{Measurement of oxidative stress biomarkers}

Lipid peroxidation (LPO) was evaluated by the thiobarbituric acid-reactive substances (TBARS) assay [29]. Results are expressed as nanomol malondialdehyde (MDA) equivalents/mg protein using an extinction coefficient $(\varepsilon)$ of $1.56 \times$ $10^{5} \mathrm{M}^{-1} \mathrm{~cm}^{-1}$.

Protein carbonyl groups (ketones and aldehydes) were determined according to Levine et al. [30]. Results are expressed as nanomol DNPH incorporated $/ \mathrm{mg}$ protein $\left(\varepsilon=2.2 \times 10^{4} \mathrm{M}^{-1} \mathrm{~cm}^{-1}\right)$.

Mieloperoxidase (MPO) activity was measured according to the method followed by Suzuki et al. [31] and Andrews et al. [32] with slight modifications as reported by Dinis-Oliveira et al. [33]. Results are expressed as enzyme activity in U/g protein.

Glutathione and glutathione disulfide (GSH and GSSG) concentrations were determined by the 5,5'-dithiobis-2-nitrobenzoic acid-GSSG reductase recycling assay previously described [34]. Results are expressed as nanomol GSH or GSSG/mg protein.

Copper/zinc superoxide dismutase (CuZnSOD) and manganese superoxide dismutase (MnSOD) were assayed using the method of Flohé and Otting [35] with modifications set by Dinis-Oliveira et al. [36]. Results are expressed as enzyme 
activity in $\mathrm{U} / \mathrm{mg}$ protein. $1 \mathrm{U}$ of SOD activity is defined as the amount of enzyme required to inhibit the rate of nitrotetrazolium blue (NTB) reduction by $50 \%$.

Catalase activity (CAT) was measured according to the method of Aebi [37]. Results were expressed in U/mg protein $\left(\varepsilon=39.4 \mathrm{M}^{-1} \mathrm{~cm}^{-1}\right)$.

Glutathione peroxidase (GPx) activity was measured according to the method of Flohé [38]. Results were expressed as enzyme activity in U/mg protein $(\varepsilon=$ $6.22 \mathrm{mM}^{-1} \mathrm{~cm}^{-1}$ ). $1 \mathrm{U}$ of GPx represents $1 \mathrm{mmol} \mathrm{NADPH}$ oxidized/min per mg protein.

Gutathione S-transferase (GST) activity was determined according to Warholm et al. [39]. Results are expressed as enzyme activity in U/mg protein (1 U enzyme activity is defined as the amount required to catalyse the synthesis of $1 \mu \mathrm{mol}$ of S-2,4-dinitrophenylgutathione per $\min$ at $30^{\circ} \mathrm{C}$ ).

\section{Statistical analysis}

Results are expressed as means \pm SEM. Comparison of results from control and excipient groups was performed by application of the non-parametric KruskalWallis test [40]. Statistical significance was established at the standard probability value $(P<0.05)$.

\section{RESULTS}

Protein, LPO and carbonyl group quantification, as well as the activity of different antioxidant enzymes used as inflammatory and tissue stress biomarkers were determined in the lung of rats exposed to lactose or chitosan by inhalation route.

Figures 1 and 2 show the results obtained for oxidative stress-related biomarkers assayed in control, lactose and chitosan groups. The most important finding was obtained for MPO activity (U/g protein) and GSSG lung concentrations ( $\mathrm{nmol} / \mathrm{mg}$ protein) that showed a relevant decrease for chitosan group compared to control: $4.67 \pm 2.27$ versus $15.10 \pm 7.27(P=0.011)$ for $\mathrm{MPO}$ and $0.89 \pm 0.68$ versus $2.02 \pm 0.22(P=0.014)$ for GSSG. For CAT (U/mg protein), a decrease was found in the lactose group compared to control $(18.22 \pm 3.72$ versus $13.25 \pm 2.58$; $P=0.05)$.

Mean TBARS concentrations (nmol/mg protein) were $0.096 \pm 0.018,0.123 \pm$ 0.075 and $0.098 \pm 0.027$ for control, lactose and chitosan groups, respectively, with no statistical differences. Regarding carbonyl groups determination, animals exposed to distilled water, lactose or chitosan showed a similar behaviour with mean values of $4.56 \pm 1.15,4.33 \pm 0.83$ and $3.51 \pm 1.16$, respectively.

For GST and GPx activities (U/mg protein) mean values of $7.19 \pm 0.89$ (control), $5.88 \pm 0.92$ (lactose) and $6.80 \pm 1.36$ (chitosan) for the former and $82.94 \pm 29.60$ (control), $83.73 \pm 30.45$ (lactose) and $84.25 \pm 10.08$ (chitosan) for the latter were obtained, with no statistical significant differences in any case. 

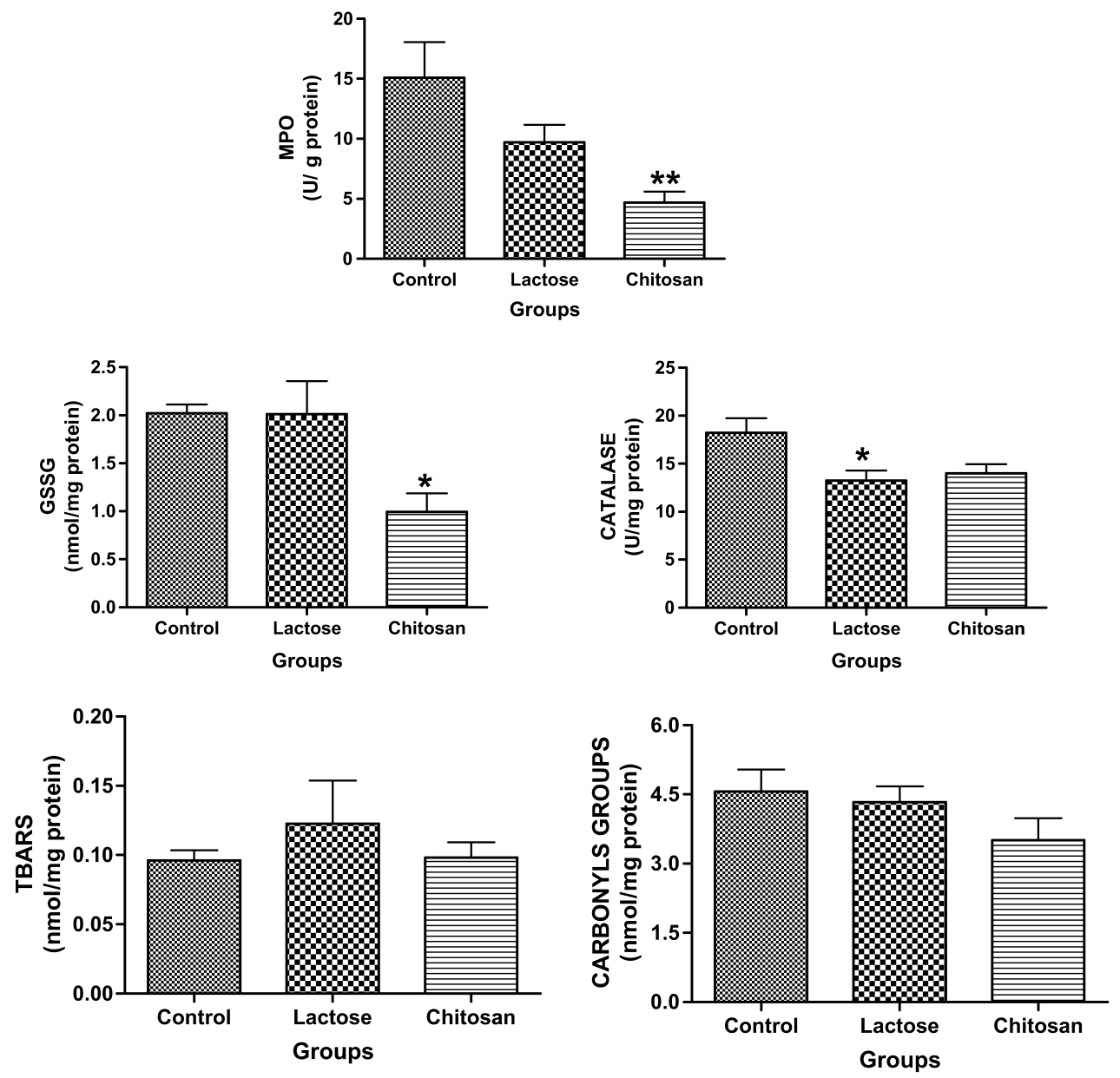

Figure 1. MPO lung activity (U/g protein), GSSG (nmol/mg protein), CAT (U/mg protein), lipid peroxidation (nmol MDA/mg protein) and carbonyl group content (nmol/mg protein) in control, lactose and chitosan groups. Values are given as means \pm SEM $(n=6) . P>0.05, * P<0.05$, $* * P<0.01$.

Results of GSH lung concentrations (nmol/mg protein) and the activities of $\mathrm{ZnCuSOD}$ and MnSOD (U/mg protein) did not show statistical significance between groups showing the following mean values: $25.52 \pm 7.11$ (control), $29.02 \pm$ 7.88 (lactose) and $31.61 \pm 9.38$ (chitosan) for GSH; $0.51 \pm 0.18$ (control), $0.41 \pm$ 0.14 (lactose) and $0.31 \pm 0.0733$ (chitosan) for ZnCuSOD and $0.0464 \pm 0.012$ (control), $0.0589 \pm 0.0302$ (lactose) and $0.0456 \pm 0.0065$ (chitosan) for MnSOD.

\section{DISCUSSION}

According to our results lactose does not affect the pulmonary system of the rat when administered at a dose of $20 \mathrm{mg}$ by inhalation route since all the biomarkers 

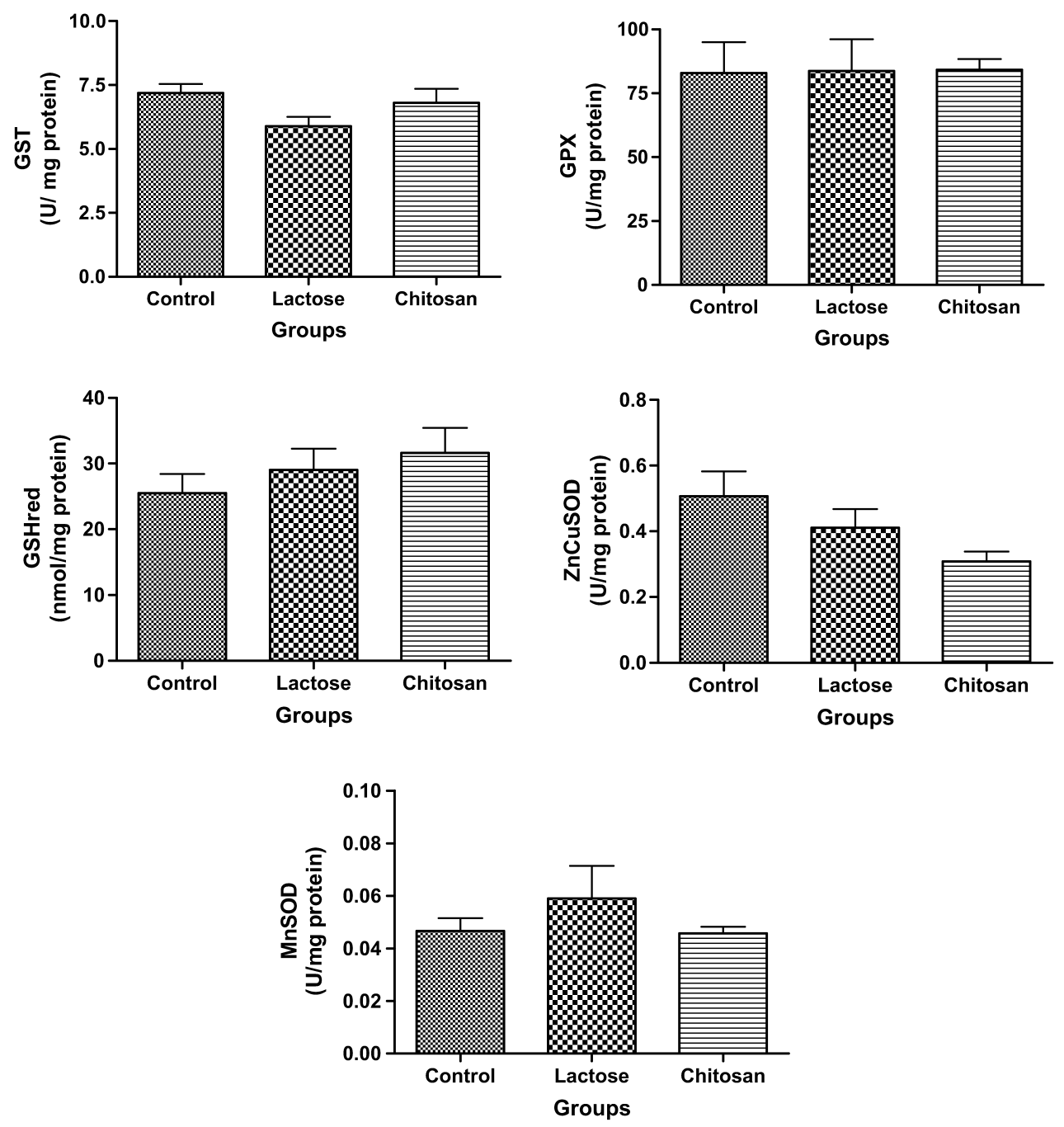

Figure 2. GST (U/mg protein), GPX lung activity (U/mg protein), concentration of GSHGred (nmol/mg protein) and activities of $\mathrm{ZnCuSOD}$ and $\mathrm{MnSOD}$ (U/mg protein) in control, lactose and chitosan groups. Values are given as means $\pm \operatorname{SEM}(n=6) . P>0.05$ for these markers.

assayed showed no statistically significant difference with respect to the control group, although CAT activity showed a slight decrease in animals receiving lactose. In lungs, catalase is localized in peroxisomes and in the cytoplasm of alveolar type II pneumocytes and macrophages, a reduction of this enzyme being likely related to a lower neutrophil recruitment. Catalase activity seems to be induced by hyperoxia, oxidants and cytokines [41], which is the opposite of the results observed in the present study that are in agreement with previous data on biocompatibility and safety of lactose when used for pulmonary administration [7-10]. Considering that the high doses used in the present study failed to produce toxicological effects on 
the lung tissue, these results confirm the behaviour of lactose per se as an inactive ingredient for pulmonary delivery, under the present experimental conditions.

The results obtained with chitosan provided some significant changes when compared to control group, although also not indicative of toxic effects. Differences were observed for GSSG levels and MPO activity, which decreased significantly to values representing $44 \%$ and $31 \%$ of control values, respectively, while a tendency for a decrease in catalase activity was also observed. MPO and catalase results may be explained by a lower recruitment of neutrophils, as explained above for lactose. The reduction in GSSG concentration in the lung is also an interesting effect since it derives from the antioxidant activity of GSH. GSH is present in high concentrations in lung epithelial lining fluid [42] and has an important role in maintaining the integrity of the airspace epithelium by playing a vital role in drug metabolism and detoxification, in both type II alveolar cells in vitro and in lungs in vivo [43]. From results obtained with GSSG and MPO an oxidative-stress-protective effect might be attributed to chitosan, since a reduction of inflammatory cells lung infiltration (assessed by quantification of MPO activity) implies less ROS production. More studies on this topic would be interesting and necessary to confirm or contradict the above statement.

Discrepancies are found between our results and those previously found by Huang et al. [13]. These authors reported significant inflammatory response in the lung of the rats at doses of $2-10 \mathrm{mg} / \mathrm{kg}$ of chitosan, while no toxicological effects were detected in our study using a dose of $20 \mathrm{mg}$ which corresponds to $60-70 \mathrm{mg} / \mathrm{kg}$ for $308.17 \pm 17.64 \mathrm{~g}$ of mean body weight. This may be due to differences in the experimental protocol since the above authors administered chitosan microparticles instead of the product dissolution. Despite the microparticles were reported to be of spherical shape, with a size distribution from 1 to $4 \mu \mathrm{m}$, a high positive charge and a density of $0.38 \mathrm{~g} / \mathrm{cm}^{3}[44,45]$, all properties that have shown to be adequate for pulmonary therapy $[46,47]$, the inflammatory effects observed could be attributed to their physical properties. In fact, their high cationic charge, which is related to the degree of deacetylation, could be the cause of the toxicological effects observed since cationic liposomes have also been reported to mediate pulmonary inflammation due to surface charges [48-50]. Aggregation of microparticles in the tracheal cannula while moving down to the lung or differences in molecular weight of chitosan used might also be responsible for the negative effects reported.

\section{CONCLUSIONS}

The present study provides a methodological approach to evaluate the pulmonary safety/toxicity of products assayed as pharmaceutical excipients for inhalation delivery and reveals that lactose and chitosan per se do not produce oxidative stress or inflammatory effects on the rat lungs after administration of doses as high as $70 \mathrm{mg} / \mathrm{kg}$ by inhalation route. A protective effect against oxidative stress might even be attributed to chitosan as far as some biomarkers reached values 
significantly lower than those observed in control group when this product was inhaled. Nevertheless, high caution must be taken regarding chemical composition (particularly for chitosan) and technological processes applied to these products during drug formulation, in particular for dry powder inhalators.

\section{Acknowledgements}

The authors acknowledge the Consejería de Educación de la Junta de Castilla y León and the Fundaçao para Ciencia e a Tecnologia (Portugal) for PhD grants (Orden EDU/1490/2003 and SFRH/BD/13707/2003, respectively).

\section{REFERENCES}

1. J. J. de George, C. H. Ahn, P. A. Andrews, M. E. Brower, Y. S. Choi, M. Y. Chun, T. Doo, D. Y. Lee-Ham, W. D. McGuinn, L. Pei, L. F. Sancillo, W. Schmidt, H. V. Sheevers, C. J. Sun, S. Tripathi, W. M. Vogel, V. Whitehurst, S. Willians and A. S. Taylor, Regul. Toxicol. Pharmacol. 25, 189 (1997).

2. D. C. Thompson, in: Pharmaceutical Inhalation Aerosol Technology, A. J. Hickey (Ed.), p. 31. Marcel Dekker, New York, NY (2004).

3. S. Pearce, Manuf. Chem. Aerosol News 57, 77 (1986).

4. H. G. Brittain, S. J. Bogdaniwich, D. F. Bugay, J. De Vicentis, G. Lewen and A. W. Newman, in: Analytical Profiles of Drug Substances, K. Florey (Ed.), p. 368. Academic Press, Sidcup (1991).

5. F. W. Goodhart, in: Handbook of Pharmaceutical Excipients, 2nd edn, A. H. Kibbe (Ed.), p. 252. The Pharmaceutical Press, London (1994).

6. Real Farmacopea Española, 3rd edn, p. 2009. National Committee for the Pharmacopeia, Ministerio de Sanidad y Consumo, Madrid (2005).

7. P. Baldrick and D. G. Bamford, Food Chem. Toxicol. 35, 719 (1997).

8. D. Wheatley, Curr. Ther. Res. 30, 655 (1981).

9. A. M. Edwards and A. Chambers, Curr. Med. Res. Opin. 11, 283 (1989).

10. R. Shaw, C. Burgess, S. Anderson, L. Stone, S. Tohill and J. Crane, Eur. Respir. J. 7 (Suppl. 18), 204S (1994).

11. L. Illum, Pharm. Res. 15, 1326 (1998).

12. V. Dodane and V. D. Vilivalam, Pharm. Sci. Technol. Today 1, 246 (1998).

13. Y. C. Huang, A. Vieira, K. I. Huang, M. K. Yeh and C. H. Chiang, J. Biomed. Mater. Res. A 75, 283 (2005).

14. T. J. Aspden, L. Illum and O. Skaugrud, Proc. Intl. Symp. Control. Rel. Bioact. Mater. 22, 550 (1995).

15. R. J. Soane, M. Frier, A. C. Perkins, N. S. Jones, S. S. Davis and L. Illum, Int. J. Pharm. 178, 55 (1999).

16. M. Sakagami, K. Sakon, W. Kinoshita and Y. Makino, J. Control. Rel. 77, 117 (2001).

17. H. Okamoto, S. Nishida, H. Todo, Y. Sakakura, K. Iida and K. Danjo, J. Pharm. Sci. 92, 371 (2003).

18. M. Bivas-Benita, K. E. Van Meijgaarden, K. L. Franken, H. E. Junginger, G. Borchard, T. H. Ottenhoff and A. Geluk, Vaccine 22, 1609 (2004).

19. K. Regnström, E. G. Ragnarsson, M. Fryknäs, M. Köping-Höggard and P. Artursson, Pharm. Res. 23, 475 (2006).

20. A. Grenha, B. Seijo and C. Remuñán-López, Eur. J. Pharm. Sci. 25, 427 (2005).

21. K. Yamada, M. Odomi, N. Okada, T. Fujita and A. Yakamoto, J. Pharm. Sci. 94, 2432 (2005). 
22. P. Baldrick, Regul. Toxicol. Pharmacol. 32, 210 (2000).

23. D. Costa, A. P. Marques, R. L. Reis, J. L. Lima and E. Fernandes, Free Radic. Biol. Med. 40, 632 (2006).

24. H. G. Gardner, J. Agric. Food Chem. 23, 129 (1975).

25. L. M. Chapman, B. R. Rubin and R. W. Gracy, J. Rheumatol. 16, 15 (1989).

26. E. D. Harris, FASEB J. 6, 2675 (1992).

27. J. Schultz and K. Kaminker, Arch. Biochem. Biophys. 96, 465 (1962).

28. O. H. N. Lowry, N. J. Rosebrough, A. L. Farr and R. J. Randall, J. Biol. Chem. 193, 265 (1951).

29. J. A. Buege and S. D. Aust, Methods Enzymol. 52, 302 (1978).

30. R. L. Levine, J. A. Willians, E. R. Stadtman and E. Shacter, Methods Enzymol. 233, 346 (1994).

31. K. Suzuki, H. Ota, S. Sasagawa, T. Sakatani and T. Fujikura, Anal. Biochem. 132, 345 (1983).

32. P. C. Andrews and N. I. Krinsky, Anal. Biochem. 127, 346 (1982).

33. R. J. Dinis-Oliveira, J. A. Duarte, F. Remiao, A. Sánchez-Navarro, M. L. Bastos and F. Carvalho, Toxicology 227, 73 (2006).

34. C. Vandeputte, I. Guizon, I. Genestie-Denis, B. Vannier and G. Lorenzon, Cell. Biol. Toxicol. 10, 415 (1994).

35. L. Flohé and F. Otting, Methods Enzymol. 105, 93 (1984).

36. R. J. Dinis-Oliveira, F. Remiao, J. A. Duarte, R. Ferreira, A. Sánchez Navarro, M. L. Bastos and F. Carvalho, Free Radic. Biol. Med. 41, 1213 (2006).

37. H. Aebi, Methods Enzymol. 105, 121 (1984).

38. L. Flohé and W. A. Günzler, Methods Enzymol. 105, 114 (1984).

39. M. Warholm, C. Guthenberg, C. Bahr and B. Mannervik, Methods Enzymol. 113, 499 (1985).

40. W. H. Kruskal and W. A. Wallis, J. Am. Stat. Ass. 47, 583 (1952).

41. I. Rahman, S. K. Biswas and A. Kode, Eur. J. Pharmacol. 533, 222 (2006).

42. A. M. Cantin, S. L. North, R. C. Hubbard and R. G. Crystal, J. Appl. Physiol. 63, 152 (1987).

43. X. Y. Li, K. Donaldson, I. Rahman and W. MacNee, Am. J. Respir. Crit. Care Med. 149, 1518 (1994).

44. Y. Huang, M. Yeh and C. Chiang, Int. J. Pharm. 242, 239 (2002).

45. Y. C. Huang, M. K. Yeh and S. N. Chiang, J. Microencapsul. 20, 459 (2003).

46. D. A. Edwards, J. Hanes, G. Caponetti, J. Hrkach, A. Ben-Jebria, M. L. Eskew, J. Mintzes, D. Deaver, N. Lotan and R. Langer, Science 276, 1868 (1997).

47. A. Ben-Jebria, D. Chen, M. L. Eskew, R. Vanbever, R. Langer and D. Edwards, Pharm. Res. 16, 555 (1999).

48. R. K. Scheule, J. A. George, R. G. Bagley, J. Marshal, J. M. Kaplan, G. Y. Akita, K. X. Wang, E. R. Lee, D. J. Harris, C. Jiang, N. S. Yew, A. E. Smith and S. H. Cheng, Human Gene Ther. 8, 689 (1997).

49. S. Dokka, D. Toledo, X. Shi, V. Castranova and Y. Rojanasakul, Pharm. Res. 17, 521 (2000).

50. M. Emerson, L. Renwick, S. Tate, S. Rhind, E. Milne, H. Painter (née Alsop), A. C. Boyd, G. McLachlan, U. Griesenbach, S. H. Cheng, D. R. Gill, S. C. Hyde, A. Baker, E. W. Alton, D. J. Porteous and D. D. S. Collie, Mol. Ther. 8, 646 (2003). 